\title{
GENDER INFLUENCE ON THE INCOME OF MAIZE FARMERS IN GIWA LOCAL GOVERNMENT AREA OF KADUNA STATE
}

\author{
Oyinbo Oyakhilomen, Researcher \\ Ahmadu Bello University, Zaria, Nigeria \\ E-mail: ooyakhilomen@gmail.com
}

\begin{abstract}
The purpose of this study was to determine the influence of gender on the farm income of maize farmers in the study area. Primary data obtained using structured questionnaire were employed in the study and the data were collected from a sample size of 100 maize farmers comprising of 70 males and 30 females. The key finding of the study is that gender was significant at $1 \%$ probability level and had a positive influence on income of the maize farmers and this was attributed to the disparity in the access to production resources and supportive services by the male and female maize farmers with men having more favourable access to production resources especially land and other supportive services than women. Based on this finding, it is recommended that gender inequality in the distribution of resources, information and other farm inputs should be minimized so as to ensure that women have access to resources for production just as men do thereby enhancing their productivity and income.
\end{abstract}

\section{KEY WORDS}

Females; Gender; Income; Maize farmers; Males; Productivity.

Gender is the social differences between men and women (Oladeebo, 2012).It focuses on the relationship between men and women in terms of their roles, access to and control over scarce resources, division of labour and other needs (Imoh and Nwachukwu (2009).The advantage of a gender perspective is that it allows for the advancement of gender equality and equity regardless of whether it is women or men whose position needs to be advanced.In most countries, women constitute half of the population. Therefore, any development process that ignores the life-chances of half the population cannot address the problem of poverty and the crisis of sustainability (Anyawu, 2010). This is why at this critical juncture of global change; it is a necessity for the development process to fully incorporate an agenda for women's empowerment by including women's realities in the fullest sense.

Despite the pivoted role-played by women in agriculture, very few of them own/control productive resources (Opio, 2003). Such resources are land, credit, technical services, market outlets, information etc. This coupled with their long-term low socioeconomic status, renders them generally unable to take key decisions over use of such resources and benefits accruing from farm production. They have therefore not received equitable decision making privileges. Hence for women and men, to have a positive effect on their productivity, income and food security, agricultural research and extension will have to take into account gender needs and constraints.

Gender inequality remains a problem that has characterized the Nigerian agricultural climate (Olagunjuet al., 2012). In Southern part of Nigeria women are meant to do most of farm work and haveownership of the farms while in the Northern part, men do most of the farm work andhave ownership of farms. The pervasiveness of gender stratification in the distribution of production resources, information and even access to appropriate technologies is an issue of great importance (Simonyanet al., 2012).

From the perspective of Commonwealth secretariat (2001), women have always played an important role in agriculture, undertaking a wide range of activities relating to food production, processing and marketing. Beyond the farm, women play a key role in land and water management in all developing countries. Women are most often the collectors of water, firewood and fodder. They have access to a store of local knowledge on the medicinal use of plants; they have been in the forefront of soil conservation programmes; and it is women who perform most of the household labour devoted to animals. As migration to the 
cities of the developing world gathers speed, women carry with them these rural skills and are responsible for the growth of urban and peri-urban agriculture, which is now recognised as being vital to food security in cities.

Maize is one of the important grains in Nigeria, not only on the basis of the number of farmers that engaged in its cultivation, but also in its economic value (Olaniyi and Adewale, 2012) and this points to the significant role of maize production to sustainable development of rural economy, food security and poverty reduction especially in rural areas of Nigeria. Despite the economic importance of maize to the teeming populace in Nigeria, it has not been produced to meet food and industrial needs of the country and this could be attributed to low productivity from maize farms or that farmers have not adopted improved technologies for maize production (Onuket al., 2010). Efforts to improve and sustain maize technologies have met with some success, as improved maize varieties are now grown in most areas of Northern Nigeria and in appreciable quantity across other agro ecological zones of Southern Nigeria (Olaniyi and Manyong, 2007).

There is an increasing literature on gender issues in agricultural production on one hand and maize production on the other hand but there seems to be an information gap on the influence of gender on the farm income of maize farmers. Therefore, the objective of this study is to determine the influence of gender on the farm income of maize farmers thereby filling the existing gap in research. The hypothesis put forward in the study is as follows:

Null form $\left(H_{0}\right)$ : There is no significant relationship between gender and farm income of maize farmers in the study area.

Alternative form $\left(H_{a}\right)$ : There is significant relationship between gender and income of maize farmers in the study area.

\section{METHODOLOGY}

Description of Study Area. The study was conducted in Giwa Local Government Area of Kaduna State, Nigeria. GiwaLocal Government Area of Kaduna State is located in the plain of the Northern part of Kaduna State. It lies between latitude $12.20^{\circ} \mathrm{N}$ to $12.52^{\circ} \mathrm{N}$ and longitude $7.0^{\circ} \mathrm{E}$ to $7.5^{\circ} \mathrm{E}$. The Local Government Areahad an estimated population of 286,427 people in 2006 (NPC, 2006) with a projected population of 332, 255 people in 2011 at a population growth rate of 3.2 per cent. The Local Government Area is blessed with floodplains popularly known as Fadama lands. These floodplains are characterized by availability and accessibility to both open surface and under ground water. The mean annual rainfall varies from $635 \mathrm{~mm}$ to $1,524 \mathrm{~mm}$. There are two distinct seasons in the study area; the rainy season and the dry season. The rainy season commences between April and June. The length of the rainy season varies from 90 days to 200 days. The dry season extends from October to early June and is marked by hot dry north eastern harmattan winds. The lowest mean temperature is usually recorded during the harmattan period. This occurs between November and February with the range from $18^{\circ} \mathrm{C}-23^{\circ} \mathrm{C}$. The major source of livelihood in this area is agriculture and the bulk of agricultural production is undertaken by small farmers of which women are included. The major crops grown in the area are maize, cowpea, tomatoes, pepper, onions, wheat, lettuce, carrot, garden egg plant, amaranthus and sugarcane.

Sampling procedure, data collection and analysis. A combination of random and purposive sampling techniques was employed in this study. Five districts were randomly selected out of the eleven districts on the study area. The selected districts are Giwa, Shika, Kaya, Fatika and Yakawada districts. 20 maize farmers were purposively selected from each of the districts to give a sample size of 100 maize farmers comprising of 60 male farmers and 40 female farmers and the reason for the use of purposive sampling in the selection of the maize farmers was due to the unavailability of reliable sampling frame of maize farmers in the study area. The data used in this study were collected using structured questionnaire. The data collected included the socioeconomic characteristics of the maize farmers, inputs used in maize production and income of the maize farmers. The analysis of the data was done using a multiple regression analysis. 
Model specification. The influence of gender on the income of maize farming households in Giwa Local Government Area of Kaduna State, Nigeria was modelled implicitly as:

$$
Y=f\left(X_{1}\right)
$$

To avoid omission of vital variables and mis-specification of the model, other socioeconomic and institutional variables which could influence income were included in the model. The explicit form of the model was given as:

$$
Y=b_{0}+b_{1} X_{1}+b_{2} X_{2}+b_{3} X_{3}+b_{4} X_{4}+u
$$

where $Y=$ Farm income of maize farmers $(\mathbb{A}) ; X_{1}=$ Gender of household head (Dummy: 1 for male, 0 for female); $X_{2}=$ Farm size(ha); $X_{3}$ = Level of education (years of formal schooling); $X_{4}=$ Membership of association (years); $X_{5}=$ Access to extension (number of extension contacts); $X_{6}=$ Amount of credit obtained ( $\left.\#\right) ; X_{7}=$ Farming experience (years); $X_{8}=$ Irrigation (Dummy: 1 for involvement in irrigation, 0 for non-involvement in irrigation); $b_{0}=$ Constant term; $b_{1}-b_{8}=$ Estimated coefficients of the independent variables; $u=$ Error term.

\section{RESULTS AND DISCUSSION}

The result of the regression analysis showing the influence of the influence of gender and other variables(farm size, level of education, membership of association, access to extension, amount of credit obtained, farming experience and irrigation) on the farm income of maize farming households in the study area is presented in Table 1 . The adjusted $R$ Square of 0.87 implies that 87 per cent in the variability of the annual income of maize farming households in the study area is explained by the combined effect of the explanatory variablesused in the study. The goodness of fit of the model was deduced from the F-statistic of 27.712and this indicates that the model gave a good fit for the analysis.

The result indicates that genderof the maize farmerswas significant $(p<0.01)$ and had a positiveinfluence on the annual farm income of the maize farmers. A plausible explanation for this finding is the issue of gender inequality in the access to production resources especially land, supportive services such as extension and decision power by the maize farmers with male farmers having favourable access to resources than female farmers. This is in line with other researchers such as Rahman (2009) who asserted that even though it has been recognized that women play major role in food production and processing, they have more difficulties in gainingaccess to resources such as land, credit and productivity-enhancing inputs and services than men. Ajani (2008) also noted that despite significant contributions of women to economic development and the household, overall, they have less access to land, capital, credit, technology and training than men do. Oladeebo (2012) was of the opinion that rural women have less access to resources necessary to generate stable incomes and are frequently subject to laws that further compromise earning potential. He further noted that laws often prohibits women from owning property or signing financial contract without a husband's signature, and women are typically ineligiblefor institutionally provided resources such as credit andtraining. The implication of this result is that gender equity in the access to productive resources by both genders should be pursued as much as possible so as to enhance production and invariably the income of the maize farmers.

Farm size was significant $(p<0.1)$ and had positive influence on income of the maize farmers. The implication of the result is that the larger the area under cultivation by the farmers, the greater the farm income of the farmers. The level of education of the farmers was significant $(p<0.1)$ but was not in line with a priori expectation as it had negative relationship with the income of the maize farmers. This could be due to the incidence occupational mobility from farm to non-farm occupation as the farmers gain more educational qualification. Access to extension was significant $(p<0.01)$ and had the expected positive relationship with the income of the farmers and this implies that as the number of extension 
contacts of the farmers increases, there is the tendency of an increase in the income of the farmers. The farming experience of the farmers was significant $(p<0.01)$ and had a negative relationship with the income of the farmers. This result is contrary to a priori expectation and it could be explained on the basis that as some farmers attain more years of farming experience, they tend to adhere strictly to the old farming practices they are used to and are reluctant to adopt new farming practices that can enhance their farm productivity and invariability their farm income. Membership of association and irrigation were found to be insignificant and had negative relationship with the income of the farmers which is against a priori expectation.

Table 1 - Ordinary least squares regression estimates

\begin{tabular}{|c|c|c|c|}
\hline Variable & Coefficient & Standard error & T value \\
\hline Constant & 353248.505 & 109173.575 & 3.236 \\
\hline Gender & $178937.358^{* * *}$ & 66671.360 & 2.684 \\
\hline Farm size & $10331.695^{*}$ & 5300.044 & 1.949 \\
\hline Level of Education & $-8793.286^{*}$ & 4944.088 & -1.779 \\
\hline Membership of association & -3196.499 & 5940.490 & -0.538 \\
\hline Access to extension & $154706.210^{* * *}$ & 60714.183 & 2.548 \\
\hline Amount of credit obtained & $1.320^{* * *}$ & 0.468 & 2.818 \\
\hline Farming experience & $-5284.519^{* *}$ & 2382.681 & -2.218 \\
\hline Irrigation & -51578.140 & 49653.380 & -1.039 \\
\hline Adjusted R square & 0.87 & -1 & - \\
\hline F statistic & 27.712 & - & - \\
\hline
\end{tabular}

NB: * implies 0.1 probability level

** implies 0.5 probability level

*** implies 0.01 probability level

Using the result on Table 1, the hypothesis which stated that gender had no significant influence on the income of the maize farmers is rejected and the alternative which stated that gender had significant influence on the income of the maize farmers is accepted.

\section{CONCLUSION AND RECOMMENDATION}

This study investigated the influence of gender on the farm income of maize farming households in Giwa Local Government Area of Kaduna State using primary data elicited using structured questionnaire from a cross section of 70 male farmers and 30 female farmers. The result of the data analysis showed that gender was significant at $1 \%$ probability level and had a positive influence on income of the maize farmers and this was attributed to the variation in the ability of the male and female maize farmers to access production resources and supportive services with men being more favourably disposed to agricultural inputs than women. Other factors that were found to have influenced the income of the maize farmers are farm size, level of education, access to extension, amount of credit obtained and farming experience.In the light of the findings of the study, it is recommended that gender inequality in the distribution of resources, information and other farm inputs should be minimized so as to ensure that women have access to resources for production just as men do thereby enhancing their productivity and income.

\section{REFERENCES}

[1] Ajani, O.I.Y. (2008). Gender Dimensions of Agriculture, Poverty, Nutrition and Food Security in Nigeria. Nigeria Strategy Support Program (NSSP). Background Paper No. NSSP 005. pp. $1-47$.

[2] Anyawu, J.C. (2010). Poverty in Nigeria: A Gendered Analysis. The African Statistical Journal, 11: $39-61$. 
[3] Commonwealth secretariat, (2001). Gender Mainstreaming in Agriculture and Rural Development. A Reference Manual for Governments and Other Stakeholders. pp 1 24. ISBN: 0-85092-606-8.

[4] Imo, A. N. and Nwachukwu E. O. (2009). Analysis of Gender Participation in the Adoption of Improved Sweet Potato Varieties in Ishielu, Ebonyi State, Nigeria. Nigeria Journal of Rural Sociology, 9 (1):161-166.

[5] Oladeebo, J.O. (2012). Technical Efficiency and Rural Poverty among Farmers in Nigeria: A Gender Perspective. Global Journal of Science Frontier Research Agriculture and Veterinary Sciences, 12(8): $1-8$.

[6] Olaniyi, O.A. andAdewale, J.G. (2012). Assessment of Utilization of Agricultural Information in Maize Production among Rural Youth: Panacea for Sustainable Food Security in Nigeria. International Journal of Sustainable Development, 5(2): 75 - 86.

[7] Olaniyi, O.A. andManyong, V. (2007). Risk Aversion and Sustainable Maize Production in Nigeria: Some Challenges and Prospects for Agricultural and Economic Development. African Association of Agricultural Economics (AAAE) Conference Proceedings. pp. 177-182.

[8] Olagunju, F.I., Fakayode, S. B., Babatunde, R. O.and Ogunwole-Olapade, F. (2012). Gender Analysis of Sweet Potato Production in Osun State, Nigeria. Asian Journal of Agricultural Extension, Economics and Sociology, 2(1): $1-13$.

[9] Onuk E. G; Ogara I. M; Yahaya, H. and Nannim, N. (2010). Economic Analysis of Maize Production in Mangu Local Government Area of Plateau State, Nigeria. PAT Journal, 6 (1): 1 - 11.

[10] Opio, F. (2003). Gender mainstreaming in agriculture with special reference to Uganda: Challenges and prospects. African Crop Science Conference Proceedings, Vol. 6. 699703

[11] Rahman, S.A. (2009). Gender Issues in Food Security. A paper presented at the first biennial conference on human security in Africa at Center for security, Olusegun Obasanjo Presidential Library, Abeokuta, Ogun State, Nigeria. March 5th-8th.

[12] Simonyan J.B., Umoren, B.D. and Okoye, B.C. (2011). Gender Differentials in Technical Efficiency among Maize Farmers in Essien Udim Local Government Area, Nigeria.International Journal of Economics and Management Sciences, 1(2):17 - 23. 